\title{
Growth and Biomass Production of Moringa Cultivated in Semiarid Region as Responses to Row Spacing and Cuts
}

\author{
R. S. Santos ${ }^{a}$, J. V. Emerenciano Neto ${ }^{a}, *$, B. R. S. Bonfim ${ }^{a}$, G. S. Difante ${ }^{b}$, J. D. V. Bezerra ${ }^{a}$, F. N. Lista ${ }^{b}$, \\ A. L. C. Gurgel ${ }^{\text {, \& M. G. S. Bezerrac }}$ \\ ${ }^{a}$ Campus of Agricultural Sciences, Federal University of Vale do São Francisco, Petrolina, PE, Brazil \\ ${ }^{b}$ Faculty of Veterinary Medicine and Animal Science, Federal University of Mato Grosso do Sul, \\ Campo Grande, MS, Brazil \\ 'Federal University of the Semi-Arid Region, Mossoró, RN, Brazil \\ ${ }^{*}$ Corresponding author: joao.emerenciano@ufrn.br \\ (Received 24-07-2020; Revised 22-10-2020; Accepted 04-11-2020)
}

\begin{abstract}
The management of the moringa to produce biomass, as it is for other vegetal species, must consider some aspects that foster productivity. Among these aspects, cultivation density is a crucial element. This research aimed to assess the effects of spacing and cuts on the growth of the moringa. The treatments consisted of four spacings: $0.5 \times 1.0 \mathrm{~m} ; 0.83 \times 1.0 \mathrm{~m} ; 1.25 \times 1.0 \mathrm{~m}$; and $1.66 \times 1.0 \mathrm{~m}$. The experimental design was a randomized-block design with five repetitions. The standardization cut of the plants was performed at a one-meter height from the ground, fifty days after the seedlings transplantation. The assessments were performed every sixty days, totaling six cuts. Spacing impacted the growth and biomass production but did not affect the height of the plants. The stem diameter, branch number, and the plant's mass increased at increasing the spacing. On the other side, the total mass and the masses of the stem, the leaflet, and the petiole per hectare decreased at increasing the spacing. Spacing did not affect the ratio between leaf/stem and leaflet/petiole. Plant growth and dry matter production were highest after the first two cuts and decreased significantly from the third cut on. The spacing of $0.5 \times 1.0 \mathrm{~m}$ should be used for planting Moringa oleifera Lam. because this configuration, even reducing the gain per plant, increased the production of dry matter per unit area.
\end{abstract}

Keywords: protein-bank; cultivation density; dry matter; Moringa oleifera L.

\section{INTRODUCTION}

The moringa (Moringa oleifera Lam.) belongs to the family Moringaceae. It is a rustic tree native from India, tolerating drought, and adapted to a great variety of soils (Santos et al., 2011). It is a rapid-growth species, with flexible branches which ease the cutting management. This species requires a low amount of agricultural inputs, is resistant to pests, and its seeds do not require dormancy (Catunda et al., 2017).

Moringa culture is crucial, mainly in developing countries. In subtropical and tropical areas, as an example, its leaves are used in human nutrition, being rich in calcium, iron, phosphorus, vitamin C, beta carotene, and essential fatty acids (Leone et al., 2016). The young fruits are also eatable, and the seeds produce an oil, which is comestible and is a high-quality lubricant (Olson \& Fahey, 2011).

In north-eastern Brazil, moringa was introduced aiming to fulfill the necessities of animal nutrition due to its high regrowth potential and its adaptation to the semiarid climate. The plant also has a high level of raw protein in the leaves and satisfactory values of essential amino acids (Moyo et al., 2012; Valdez-Solana et al.,
2015). For these features, the moringa is a high-quality forage crop. Moringa oleifera consumption has been reported to improve the health status, feed conversion efficiency, growth performance, and product quality of several livestock species (Falowo et al., 2018).

The management of the moringa to produce biomass, as it is for the other vegetal species, must consider some aspects that foster productivity. Among these aspects, cultivation density is a crucial element (Padilla et al., 2017). The planting density of this species depends on the aim of its use (Sánchez et al., 2006; Leone et al., 2016). Goss (2012) assessed the initial establishment of moringa. The author observed higher dry matter production per unit area by using a 25 x $25 \mathrm{~cm}$ spacing (197.528 plants/ha) instead of more spaced cultivations. On the other hand, Mendieta-Araica et al. (2013) recommended a planting density of 167.000 plants/ha for providing a greater forage production.

Even though high densities are positively related to higher forage production (Kumalasari et al., 2017), in practical conditions, the need for labor and difficulties during harvesting make high densities impractical for small and medium farmers (Mendieta-Araica et al., 2013). Therefore, studies on planting densities more 
adapted to the practical needs of small and mediumsized properties in semiarid regions are still needed. In this context, this paper aimed to assess the effect of spacing and cuts on the growth and dry matter production of the moringa.

\section{MATERIALS AND METHODS}

The experiment was performed in the Agrarian Sciences Campus of the Federal University of the São Francisco Valley (UNIVASF) in the municipality of Petrolina, State of Pernambuco, Brazil ( $9^{\circ} 09^{\prime}$ South, 40을 22' West), between September 2017 until February 2019. According to the Köppen classification, the climate in the region is BSwh type (warm and dry region). A meteorological station placed at 30 meters from the experimental area provided the data on average rainfall and temperature (Figure 1).

The soil was classified as yellow Argissolo, with medium/sandy texture (EMBRAPA, 2006). A soil sample in the $0-40 \mathrm{~cm}$ layer was collected before the development of the experiment and destined for chemical analysis (Table 1).

The seedlings were produced in plastic bags (20 $x 30 \mathrm{~cm}$ ) filled with the ground from the experimental area and matured bovine manure at a 1:1 ratio. The seedlings were kept above the ground level on platforms in a screened environment and watered daily manually.

The ground of the area was prepared in a conventional form, plowed, and harrowed 30 days before the transplanting of the seedlings. The size of the hole for planting was $20 \mathrm{~cm}$ of length $\times 20 \mathrm{~cm}$ of wide $\times 40 \mathrm{~cm}$ of depth. The transplantation of the seedlings in the field was performed three months after the seeding. In the bag used for the transplants, 100 grams of matured bovine manure mixed with soil were used. The manure was used in order to increase water retention. It was not necessary to fertilize or correct the soil. The natural soil fertility of the experimental area showed adequate values for plant growth, according to the results obtained by Bakke et al. (2010).

The standardization cut of the plants was performed 50 days after the transplanting at a one-meter height. The drip irrigation was performed with an average water column of six mm day ${ }^{-1}$, five days a week, along all the experimental period. The area was preserved free of weeds by hand removal.

The experimental design was performed by randomized block design, with a scheme of measurements repeated over time (cuts). The treatments consisted of four spacings between the plants: $0.5 \mathrm{~m}, 0.83 \mathrm{~m}, 1.25 \mathrm{~m}$, and $1.66 \mathrm{~m}$. The spacing between the lines was fixed at $1.0 \mathrm{~m}$, with five repetitions. Each experimental unit occupied a $16.5 \mathrm{~m}^{2}$ area and was composed of three lines of plants. Only the plants of the central line were considered as a useful portion area.

Before each cut was measured, the height, the diameter of the stem, and the number of branches were measured. The height of the plants was measured by a scaled rod. The height was considered from the ground until the apical bud of the highest branch. Stem diameter was assessed at the height of ten centimeters from the ground level using a digital caliper (Rodrigues et al., 2016). The number of branches was assessed by counting all the branches emerging over the height of one meter from the ground level (cutting height).

The cuts were performed at a 60 days interval, counted starting from the standardization cut. Plants were cut at one meter above the ground level and transported to the laboratory, where the mass of the plants of each parcel was assessed using a digital balance. Representative samples of entire and uniform branches, with an average weight of $1.0 \mathrm{~kg}$, were sampled. Stem

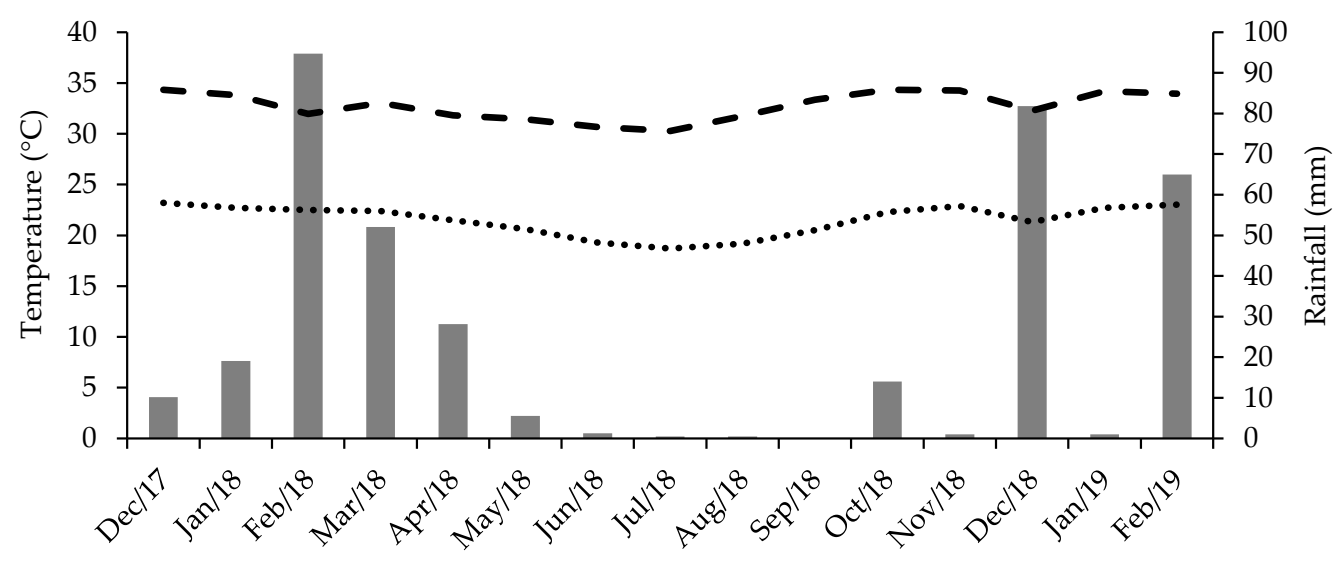

Figure 1. Rainfall, minimum and maximum temperatures from December 2017 until February 2019 Precipitation _ - Maximum temperature ...... Minimum temperature

Table 1. Chemical features of the soil in the $0-40 \mathrm{~cm}$ layer

\begin{tabular}{cccccccccc}
\hline $\begin{array}{c}\mathrm{pH} \\
\left(\mathrm{H}_{2} \mathrm{O}\right)\end{array}$ & $\begin{array}{c}\mathrm{P} \\
\left(\mathrm{mg} \mathrm{dm}^{-3}\right)\end{array}$ & $\begin{array}{c}\mathrm{Ca} \\
\left(\mathrm{cmol}_{\mathrm{c}} \mathrm{dm}^{-3}\right)\end{array}$ & $\begin{array}{c}\mathrm{Mg} \\
\left(\mathrm{cmol}_{\mathrm{c}} \mathrm{dm}^{-3}\right)\end{array}$ & $\begin{array}{c}\mathrm{K} \\
\left(\mathrm{cmol}_{\mathrm{c}} \mathrm{dm}^{-3}\right)\end{array}$ & $\begin{array}{c}\mathrm{Na} \\
\left(\mathrm{cmol}_{\mathrm{c}} \mathrm{dm}^{-3}\right)\end{array}$ & $\begin{array}{c}\mathrm{Al} \\
\left(\mathrm{cmol}_{\mathrm{c}} \mathrm{dm}^{-3}\right)\end{array}$ & $\begin{array}{c}\mathrm{H}+\mathrm{Al}\left(\mathrm{cmol}_{\mathrm{c}}\right. \\
\left.\mathrm{dm}^{-3}\right)\end{array}$ & $\begin{array}{c}\mathrm{CTC} \\
\left(\mathrm{cmol}_{\mathrm{c}} \mathrm{dm}^{-3}\right)\end{array}$ & $\begin{array}{c}\mathrm{V} \\
(\%)\end{array}$ \\
\hline 6.0 & 28.46 & 1.9 & 0.60 & 0.41 & 0.02 & 0.00 & 1.65 & 4.58 & 64 \\
\hline
\end{tabular}


and leaves were separated manually to determine the mass of each one of these components. Samples were placed in an oven with forced air circulation at $55^{\circ} \mathrm{C}$ for 72 hours. After that, the samples were weighed again to determine the dry matter weight (Silva \& Queiroz, 2002). After drying, leaves were separated by hand, dividing leaflets and petioles. The mass of each one of these components was assessed.

Data were submitted to the Lilliefors and Bartlett tests to verify the normality and homoscedasticity. After that, the data were submitted to the analysis of variance. The effect of spacing was assessed by regression analysis, choosing the models that best explained the results based on the coefficient of determination $\left(R^{2}\right)$. Tukey's test compared the effect of the cut. Both tests were performed at a 5\% significance level, using the program SISVAR 5.6 (Ferreira, 2011).

\section{RESULTS}

The height of the plant was not affected by the spacing, with an average height of $1.93 \mathrm{~m}$ (Table 2). The diameter of the stem and the number of branches per plant displayed a linear and positive association $(\mathrm{p}<0.05)$ with the spacing between the plants.
Spacing affected the mass of the plants in a linear and positive form $(\mathrm{p}<0.05)$, with the highest values corresponding to the spacing of $1.66 \times 1.0 \mathrm{~m}$ (Table 2). The total mass was adjusted to the linear and negative equation as a function of the spacing (Table 3).

The results of the mass of these components were similar to that of the total dry mass, which decreased $(p<0.05)$ linearly as the spacing was increasing. Spacing did not affect the leaf/stem and leaflet/petiole ratios with average values of 1.66 and 1.94, respectively (Table 3).

The experiment highlighted differences $(p<0.05)$ among the cuts as it refers to the height of the plants, stem diameter, number of branches, and mass of the plant. The height and mass of the plant were higher in the first two cuts compared to the other. The stem diameter and the number of branches were the highest at the sixth cut (Table 4).

The total leaves', stem, leaflet, and petiole mass per hectare followed the same tendency of the height and the mass of the plant, displaying the highest values $(p<0.05)$ in the first two cuts compared to the other. The leaf/stem ratio was the lowest $(p<0.05)$ in the two first cuts. The cuts also influenced the leaflet/petiole ratio $(p<0.05)$ with higher values in the third cut compared to the others (Table 5).

Table 2. Growth and yield of moringa grown with different spacings

\begin{tabular}{|c|c|c|c|c|c|c|}
\hline \multirow{2}{*}{ Variables } & \multicolumn{4}{|c|}{ Distance between plants (m) } & \multirow{2}{*}{ Equation } & \multirow{2}{*}{$\mathrm{R}^{2}(\%)$} \\
\hline & 0.50 & 0.83 & 1.25 & 1.66 & & \\
\hline Plant's height (m) & 1.93 & 1.86 & 2.02 & 1.93 & $\hat{y}=1.935$ & - \\
\hline Stem's diameter (mm) & 46.25 & 47.31 & 53.33 & 57.11 & $y=9.9887 x+40.412$ & 96.4 \\
\hline Number of branches & 4.80 & 4.91 & 5.96 & 6.39 & $y=1.5068 x+3.9178$ & 94.1 \\
\hline Plant mass (kg of DM) & 0.14 & 0.17 & 0.29 & 0.31 & $y=0.1621 x+0.0557$ & 92.4 \\
\hline
\end{tabular}

Note: $\mathrm{R}^{2}=$ Coefficient of determination

Table 3. Growth and morphologic composition of moringa grown with different spacings

\begin{tabular}{|c|c|c|c|c|c|c|}
\hline \multirow{2}{*}{ Variables } & \multicolumn{4}{|c|}{ Distance between plants (m) } & \multirow{2}{*}{ Equation } & \multirow{2}{*}{$\mathrm{R}^{2}(\%)$} \\
\hline & 0.50 & 0.83 & 1.25 & 1.66 & & \\
\hline Total mass (kg ha-1 $\left.\mathrm{Cut}^{-1} \mathrm{DM}\right)$ & 2871.8 & 1610.9 & 1540.0 & 891.1 & $y=-1509.9 x+3328.9$ & 84.5 \\
\hline Leaf mass $\left(\mathrm{kg} \mathrm{ha}{ }^{-1} \mathrm{Cut}^{-1} \mathrm{DM}\right)$ & 1551.3 & 846.6 & 785.7 & 485.7 & $y=-816.54 x+1782.8$ & 83.3 \\
\hline Stem mass (kg ha-1 $\left.\mathrm{Cut}^{-1} \mathrm{DM}\right)$ & 1320.5 & 764.3 & 754.3 & 405.4 & $y=-693.34 x+1546.1$ & 85.4 \\
\hline Leaf/stem ratio & 1.68 & 1.66 & 1.47 & 1.81 & $\hat{y}=1.66$ & - \\
\hline Leaflet mass (kg ha $\left.{ }^{-1} \mathrm{Cut}^{-1} \mathrm{DM}\right)$ & 966.1 & 552.7 & 513.9 & 311.1 & $y=-503.29 x+1119.4$ & 85.4 \\
\hline Petiole mass (kg ha $\left.{ }^{-1} \mathrm{Cut}^{-1} \mathrm{DM}\right)$ & 585.2 & 293.9 & 271.8 & 174.6 & $y=-313.25 x+663.41$ & 79.7 \\
\hline Leaflet/petiole ratio & 1.74 & 2.03 & 2.03 & 1.96 & $\hat{\mathrm{y}}=1.94$ & - \\
\hline
\end{tabular}

Note: $\mathrm{R}^{2}=$ Coefficient of determination

Table 4. Growth and yield of moringa according to the number of cuts

\begin{tabular}{|c|c|c|c|c|c|c|c|}
\hline \multirow{2}{*}{ Variables } & \multicolumn{6}{|c|}{ Cuts } & \multirow{2}{*}{ CV $(\%)$} \\
\hline & $1^{\circ}$ & $2^{\circ}$ & $3^{\circ}$ & $4^{\circ}$ & $5^{\circ}$ & $6^{\circ}$ & \\
\hline Plant's height (m) & $2.20^{a}$ & $2.33^{\mathrm{a}}$ & $1.90^{\mathrm{b}}$ & $1.78^{\mathrm{bc}}$ & $1.73^{\mathrm{bc}}$ & $1.56^{c}$ & 12.43 \\
\hline Stem's diameter (mm) & $42.81^{c}$ & $45.96^{\mathrm{bc}}$ & $46.48^{\mathrm{bc}}$ & $54.32^{\mathrm{ab}}$ & $55.99^{\mathrm{ab}}$ & $60.08^{a}$ & 23.41 \\
\hline Number of branches & $4.20^{\mathrm{b}}$ & $5.25^{\mathrm{b}}$ & $5.95^{\mathrm{b}}$ & $4.65^{\mathrm{b}}$ & $4.36^{\mathrm{b}}$ & $9.21^{\mathrm{a}}$ & 33.57 \\
\hline Plant mass (kg of DM) & $0.415^{\mathrm{a}}$ & $0.413^{\mathrm{a}}$ & $0.192^{\mathrm{b}}$ & $0.128^{\mathrm{bc}}$ & $0.075^{c}$ & $0.076^{c}$ & 27.51 \\
\hline
\end{tabular}

Note: $C V=$ Coefficient of variation. Means in the same row with different superscripts differ significantly $(p<0.05)$. 
Table 4. Growth and yield of moringa according to the number of cuts

\begin{tabular}{|c|c|c|c|c|c|c|c|}
\hline \multirow{2}{*}{ Variables } & \multicolumn{6}{|c|}{ Cuts } & \multirow{2}{*}{$\mathrm{CV}(\%)$} \\
\hline & $1^{\circ}$ & $2^{\circ}$ & $3^{\circ}$ & $4^{\circ}$ & $5^{\circ}$ & $6^{\circ}$ & \\
\hline Total mass $\left(\mathrm{kg} \mathrm{ha}^{-1} \mathrm{Cut}^{-1} \mathrm{DM}\right)$ & $3125.6^{\mathrm{a}}$ & $3219.2^{\mathrm{a}}$ & $1415.7^{b}$ & $984.2^{\mathrm{b}}$ & $619.2^{\mathrm{bc}}$ & $549.1^{c}$ & 26.5 \\
\hline Leaf mass (kg ha-1 Cut $\left.{ }^{-1} \mathrm{DM}\right)$ & $1840.6^{\mathrm{a}}$ & $1758.0^{\mathrm{a}}$ & $868.8^{\mathrm{b}}$ & $632.9^{\mathrm{bc}}$ & $416.9^{\mathrm{bc}}$ & $324.3^{c}$ & 22.80 \\
\hline Stem mass (kg ha- $\left.{ }^{-1} \mathrm{Cut}^{-1} \mathrm{DM}\right)$ & $1285.0^{\mathrm{a}}$ & $1461.2^{\mathrm{a}}$ & $546.9^{\mathrm{b}}$ & $351.4^{\mathrm{bc}}$ & $224.9^{c}$ & $202.3^{c}$ & 34.48 \\
\hline Leaf/stem ratio & $1.19^{\mathrm{cd}}$ & $0.9^{\mathrm{d}}$ & $2.32^{\mathrm{a}}$ & $1.76^{\mathrm{ab}}$ & $2.28^{\mathrm{a}}$ & $1.58^{\mathrm{bc}}$ & 18.68 \\
\hline Leaflet mass $\left(\mathrm{kg} \mathrm{ha}^{-1} \mathrm{Cut}^{-1} \mathrm{DM}\right)$ & $1116.6^{\mathrm{a}}$ & $1106.1^{\mathrm{a}}$ & $626.5^{\mathrm{b}}$ & $394.9^{\mathrm{bc}}$ & $283.8^{\mathrm{cd}}$ & $194.8^{\mathrm{d}}$ & 23.24 \\
\hline Petiole mass (kg ha-1 $\left.\mathrm{Cut}^{-1} \mathrm{DM}\right)$ & $723.9^{a}$ & $651.9^{a}$ & $242.3^{\mathrm{b}}$ & $237.9^{\mathrm{bc}}$ & $133.1^{\mathrm{cd}}$ & $129.4^{\mathrm{d}}$ & 23.60 \\
\hline Leaflet/petiole ratio & $1.56^{\mathrm{c}}$ & $1.71^{\mathrm{c}}$ & $2.83^{\mathrm{a}}$ & $1.71^{\mathrm{c}}$ & $2.15^{\mathrm{b}}$ & $1.68^{\mathrm{c}}$ & 11.34 \\
\hline
\end{tabular}

Note: $C V=$ Coefficient of variation. Means in the same row with different superscripts differ significantly $(p<0.05)$.

\section{DISCUSSION}

The plants grown with larger spacing displayed higher lateral growth, producing more dense canopies, with higher thickening of the stem and higher branches number, due to the lower competition among the plants, and, as a consequence, higher nutrients' availability (Kumalasari et al., 2017). Adegun \& Ayodele (2015) claim that the lower spacing between the plants on the same line might reduce the lateral growth of the plants, inducing a higher vertical growth. Even the same, our experiment displayed no difference among the height of the plants.

Mabapa et al. (2017) observed similar results as the authors assessed the effect of the density of planting in the productivity of the moringa. The authors described that the height of the plant was not affected by the different spacings and that the higher the cultivation density, the higher the production of dry matter per unity of surface occupied.

The plant's highest value mass in the spacing of $1.66 \times 1.0 \mathrm{~m}$ is due to the increase in the number of branches with the increasing of the spacing. Castro Filho et al. (2016) observed similar behavior in gliricidia (Gliricidia sepium (Jacq.) Walp.). The author observed a decrease in the yield per plant as increasing the plantation density.

There was a $226 \%$ increase in the total mass compared to the highest spacing $(1.66 \times 1.0 \mathrm{~m})$, highlighting that the total yield per unity of surface occupied may counterbalance the low yield per plant. Other studies performed with the same species highlighted that higher productions were associated with more dense plantings (Nouman et al., 2014; Basra et al., 2015; Zheng et al., 2016; Kumalasari et al., 2017).

The similarity of the age of all the plants used in the different treatments could explain there are no differences for the leaf/stem and leaflet/petiole ratios. These results may be considered satisfactory: our experiment highlighted an increase in the production of dry matter per hectare using lower spacing between the plants, without affecting the proportion of leaf/stem and leaflet/ petiole, preserving, in this form, the quality of the biomass produced.

Even the higher amount of branches at the sixth cut displayed low development and did not contribute to an increase in the plant's mass. The increase of the stem diameter was due to its uninterrupted growth during the experimental period, as the plants were cut at one meter above the ground, and the measurement of this parameter was performed at ten $\mathrm{cm}$ from the ground level. The lowest leaf/stem ratio in the first cuts was due to the higher initial growth in height. This element contributed to a higher development of the stem and, as a consequence, a lower proportion of leaves (Teixeira et al., 2010).

The lack of manuring, mainly the nitrogen one, can explain the lower development of the plants, displaying a decrease in the production along the experimental period. According to Padilla et al. (2017), moringa can extract huge amounts of nutrients from the ground, requiring proper management of the manuring to maintain the productivity stable along the time.

Sánchez et al. (2006) studied the production of moringa in Nicaragua. The authors observed a decrease in production during the second year of the study in comparison to the first. The authors suggested that the supply of nutrients in the ground might have been insufficient to preserve a constant biomass production. In another study, Lok \& Suárez (2014) assessed the effect of fertilizers on the production of moringa biomass. The authors claimed that in lack of fertilization, this species could significantly reduce the amount of nutrients in the ground.

Mendieta-Araica et al. (2013) also studied the effect of different planting densities and nitrogen fertilization concentrations. The authors suggest that moringa's productivity can be maintained stable as long as the soil is regularly provided with approximately $521 \mathrm{~kg} \mathrm{ha}^{-1}$ year $^{-1}$ $\mathrm{N}$ in conditions when the phosphorus and potassium are not limiting elements.

\section{CONCLUSION}

The spacing between the plants affected the growth and productivity of the moringa but did not affect the morphological composition of the plants. Dry matter production was higher after the first two cuts and decreased from the third cut on, considering a frequency of six cuts during one year. The spacing that produced the highest biomass was $0.5 \times 1.0 \mathrm{~m}$. This setting, even reducing the earning per plant, increased the dry matter production per area unit. 


\section{CONFLICT OF INTEREST}

The authors declare that there is no conflict of interest with any financial, personal, or other relationships with other people or organizations related to the material discussed in the manuscript.

\section{ACKNOWLEDGEMENT}

This study was financed in part by the Coordenação de Aperfeiçoamento de Pessoal de Nível Superior - Brasil (CAPES) - Finance Code 001. To the Group of Studies on Forage Tropical - GEForT/ UNIVASF for their assistance in implementing this work.

\section{REFERENCES}

Adegun, M. K., \& O. J. Ayodele. 2015. Growth and yield of Moringa oleifera as influenced by spacing and organic manures in South-Western Nigeria. Int. J. Agron. Agric. Res. 6:30-37.

Bakke, I. A., J. S. Souto, P. C. Souto, \& O. A. Bakke. 2010. Growth and forage value of moringa (Moringa oleifera Lam.) under different organic fertilization and cut intervals. Eng. Ambiental. 7:133-144.

Basra, S. M. A., W. Nouman, H. Rehman, M. Usman, \& Z. H. Nazli. 2015. Biomass production and nutritional composition of Moringa oleifera under different cutting frequencies and planting spacings. Int. J. Agric. Biol. 17:1055-1060. https://doi.org/10.17957/IJAB/15.0076

Castro Filho, E. S., E. N. Muniz, J. H. A. Rangel, G. R. A. Santos, J. A. Santana Neto, \& H. R. Araujo. 2016. Dry matter yield and bromatological composition of gliricidia in different crop densities. Ciênc. Rural. 46:1038-1043. https:// doi.org/10.1590/0103-8478cr20150782

Catunda, K. L. M., E. M. Aguiar, V. Lima Júnior, M. M. T. Rego, \& A. H. N. Rangel. 2017. Moringa oleifera: An alternative forage of multiple uses for the Brazilian semiarid. Científica. 45:437-442. https://doi. org/10.15361/1984-5529.2017v45n4p437-442

EMBRAPA (Empresa Brasileira de Pesquisa Agropecuária) - Centro Nacional de Pesquisa de Solos. 2006. Sistema Brasileiro de Classificação de solos. $2^{\text {nd }}$ ed. EMBRAPA, Rio de Janeiro.

Falowo A. B., F. E. Mukumbo, E. M. Idamokoro, J. M. Lorenzo, A. J. Afolayan, \& V. Muchenje. 2018. Multi-functional application of Moringa oleifera Lam. in nutrition and animal food products: A review. Food Res. Int. 106:317-334. https://doi.org/10.1016/j.foodres.2017.12.079

Ferreira, D. F. 2011. Sisvar: a computer statistical analysis system. Ciênc. Agrotec. 35:1039-1042. https://doi.org/10.1590/ S1413-70542011000600001

Goss, M. 2012. A study of the initial establishment of multipurpose moringa (Moringa oleifera Lam) at various plant densities, their effect on biomass accumulation and leaf yield when grown as vegetable. Afr. J. Plant Sci. 6:125-129. https://doi.org/10.5897/AJPS11.259

Kumalasari, N. R., G. P. Wicaksono, \& L. Abdullah. 2017. Plant growth pattern, forage yield, and quality of Indigofera zollingeriana influenced by row spacing. Med. Pet. 40:1419. https://doi.org/10.5398/medpet.2017.40.1.14

Leone, A., A. Spada, A. Battezzati, A. Schiraldi, J. Aristil, \& S. Bertoli. 2016. Moringa oleifera seeds and oil: Characteristics and uses for human health. Int. J. Mol. Sci. 17:2141. https:// doi.org/10.3390/ijms17122141

Lok, S. \& Y. Suárez. 2014. Effect of fertilizers on the biomass production of Moringa oleifera and on some soil indicators during the establishment. Cuban J. Agric. Sci. 48:399-403.

Mabapa, M. P., K. K. Ayisi, \& I. K.Mariga. 2017. Effect of planting density and harvest interval on the leaf yield and quality of moringa (Moringa oleifera) under diverse agroecological conditions of Northern South Africa. Int. J. Agron. 2017:e2941432. https://doi.org/10.1155/2017/2941432

Mendieta-Araica, B., E. Spörndly, N. Reyes-Sánchez, F. Salmerón-Miranda, \& M. Halling. 2013. Biomass production and chemical composition of Moringa oleifera under different planting densities and levels of nitrogen fertilization. Agric. Syst. 87:81-92. https://doi.org/10.1007/ s10457-012-9525-5

Moyo, B., S. Oyedemi, P. J. Masika, \& V. Muchenje. 2012. Polyphenolic content and antioxidant properties of Moringa oleifera leaf extracts and enzymatic activity of liver from goats supplemented with Moringa oleifera leaves or sunflower seed cake. Meat Sci. 91:441-447. https://doi. org/10.1016/j.meatsci.2012.02.029

Nouman, W., S. M. A. Basra, M. T. Siddiqui, A. Yasmeen, T. Gull, \& M. A. C. Alcayde. 2014. Potential of Moringa oleifera L. as livestock fodder crop: A review. Turk. J. Agric. For. 38:1-14. https://doi.org/10.3906/tar-1211-66

Olson, M. E., \& J. W. Fahey. 2011. Moringa oleifera: A multipurpose tree for the dry tropics. Revista Rev. Mex. Biodivers. 82:1071-1082. https://doi.org/10.22201/ ib.20078706e.2011.4.678

Padilla, C., N. Valenciaga, G. Crespo, D. González, \& I. Rodríguez. 2017. Requerimientos agronómicos de Moringa oleifera (Lam.) en sistemas ganaderos. Livest. Res. Rural. Dev. 29:e218.

Rodrigues, L. A., T. A. Muniz, S. S. Samarão, \& A. E. Cyrino. 2016. Quality of Moringa oleifera Lam. seedlings cultivated in substrates with green coconut fiber and organic compounds. Rev. Ceres. 63:545-552. https://doi. org/10.1590/0034-737X201663040016

Sánchez, N. R., S. Ledin, \& I. Ledin. 2006. Biomass production and chemical composition of Moringa oleifera under different management regimes in Nicaragua. Agrofor. Syst. 66:231-242. https://doi.org/10.1007/s10457-005-8847-y

Santos, W. R., D. B. Matos, B. M. Oliveira, T. M. Santana, M. M. Santana, \& G. F. Silva. 2011. Estudo do tratamento e clarificação de água com torta de sementes de Moringa oleifera Lam. Ver. Bras. Prod. Agroind. 13:295-299. https://doi. org/10.15871/1517-8595/rbpa.v13n3p295-299

Silva, D. J., \& A. C. Queiroz. 2002. Análise de alimentos: métodos químicos e biológicos. $3^{\text {rd }}$ ed. Viçosa, UFV.

Teixeira, V. I., J. C. B. Dubeux Junior, M. V. F. Santos, M. A. Lira Junior, M. A. Lira, \& H. M. S. Silva. 2010. Agronomic and bromatologic aspects of forage legumes from Brazilian NE. Arch. Zootec. 59:245-254. https://doi.org/10.4321/ S0004-05922010000200010

Valdez-Solana, M. A., V. Y. Mejía-García, A. Téllez-Valencia, G. García-Arenas, J. SalasPacheco, J. J. Alba-Romero, \& E. Sierra-Campos. 2015. Nutritional content and elemental and phytochemical analyses of Moringa oleifera grown in Mexico. J. Chem. 2015:1-9. https://doi. org/10.1155/2015/860381

Zheng, Y., Y. Zhang, \& J. Wu. 2016. Yield and quality of Moringa oleifera under different planting densities and cutting heights in Southwest China. Ind. Crop. Prod. 91:88-96. https://doi.org/10.1016/j.indcrop.2016.06.032 